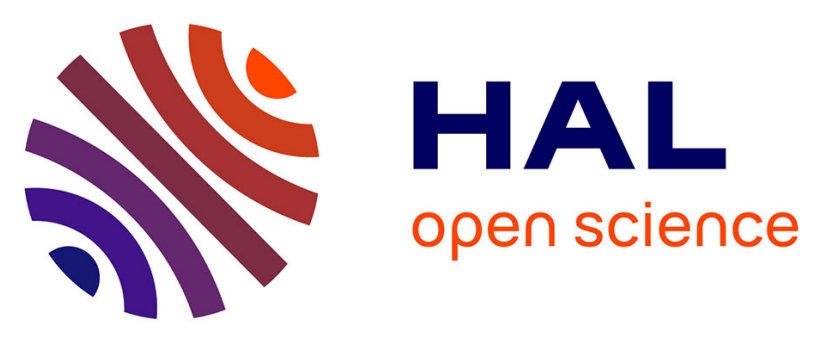

\title{
Monitoring serum HER2 levels during neoadjuvant trastuzumab treatment within the GeparQuattro trial
} Isabell Witzel, Sibylle Loibl, Gunter Minckwitz, Christoph Mundhenke, Jens

Huober, Claus Hanusch, Stephan Henschen, Maik Hauschild, Tilmann Lantzsch, Hans Tesch, et al.

\section{To cite this version:}

Isabell Witzel, Sibylle Loibl, Gunter Minckwitz, Christoph Mundhenke, Jens Huober, et al.. Monitoring serum HER2 levels during neoadjuvant trastuzumab treatment within the GeparQuattro trial. Breast Cancer Research and Treatment, 2010, 123 (2), pp.437-445. 10.1007/s10549-010-1030-9 . hal00553821

\section{HAL Id: hal-00553821 \\ https://hal.science/hal-00553821}

Submitted on 10 Jan 2011

HAL is a multi-disciplinary open access archive for the deposit and dissemination of scientific research documents, whether they are published or not. The documents may come from teaching and research institutions in France or abroad, or from public or private research centers.
L'archive ouverte pluridisciplinaire HAL, est destinée au dépôt et à la diffusion de documents scientifiques de niveau recherche, publiés ou non, émanant des établissements d'enseignement et de recherche français ou étrangers, des laboratoires publics ou privés. 


\section{Monitoring serum HER2 levels during neoadjuvant trastuzumab treatment within the GeparQuattro trial}

Isabell Witzel (1), Sibylle Loibl (3), Gunter von Minckwitz (3), Christoph Mundhenke (4), Jens Huober (5), Claus Hanusch (6), Stephan Henschen (7), Maik Hauschild (8), Tilmann Lantzsch (9), Hans Tesch (10), Kunibert Latos (11), Marianne Just (12), Jörn Hilfrich (13), Jana Barinoff (14), Christine zu Eulenburg (2), Marc Roller (3), Michael Untch (15), Volkmar Müller (1)

(1) Department of Gynecology and (2) Department of Medical Biometry and Epidemiology, University Medical Center Hamburg-Eppendorf, Hamburg, Germany, (3) German Breast Group, Forschungs GmbH, Neu Isenburg. Germany, (4) Department of Gynecology and Obstetrics, University Medical Center Kiel, Germany (5) Department of Gynecology, University of Tübingen, Germany, (6) Department of Gynecology and Obstetrics, Rotkreuzklinikum München gGmbH, Germany, (7) Johanniter-Krankenhaus, Genthin-Stendal, Germany (8) Frauenklinik Rheinfelden Betriebs GmbH, Rheinfelden, Germany (9) Krankenhaus St. Elisabeth und St. Barbara, Halle, Germany (10) CHOP GmbH / Onkologische Gemeinschaftspraxis am BethanienKrankenhaus, Frankfurt (11) Katharinen-Hospital, Unna, Germany (12) Onkologische Schwerpunktpraxis, Bielefeld, Germany (13) Frauenklinik der Henriettenstiftung Hannover, Germany (14) Dept. Gynecology \& Gynecologic Oncology, Dr. Horst Schmidt Klinik, Wiesbaden, Germany (15) Department of Gynecology and Obstetrics, HELIOS Hospital BerlinBuch, Berlin, Germany

\section{Keywords}

Breast cancer, neoadjuvant therapy, HER2, serum

\section{Abbreviations}

Correspondence to:

Dr. Volkmar Müller, MD, PhD

Department of Gynecology

University Medical Center Hamburg-Eppendorf

Martinistrasse 52

20246 Hamburg, Germany

vmueller@uke.de

Phone: +49-40-7410-52510

Fax: +49-40-7410-40070

Part of this work was presented at the $7^{\text {th }}$ European Breast Cancer Conference (EBCC) in Barcelona, Spain, in March 2010. 


\begin{abstract}
Purpose: In the context of neoadjuvant treatment for breast cancer patients different targeted therapy approaches are currently evaluated in clinical trials. Serum markers could help to monitor and optimize such treatment strategies.
\end{abstract}

Methods: We investigated HER2 serum levels (sHER2) in 175 breast cancer patients participating in the GeparQuattro trial. This study incorporated neoadjuvant chemotherapy (NT) approaches and additional trastuzumab treatment for all patients with HER2-positive tumors. sHER2 levels were measured by ELISA before initiation of NT and after NT (pre-surgery) in a HER2 positive $(n=90)$ and a HER2 negative patient cohort $(n=85)$.

Results: Median pre-chemotherapy sHER2 levels were higher in patients with positive HER2 status of the primary tumor than in patients with negative HER2 status (14.9 $\mathrm{ng} / \mathrm{ml}$ versus 7.7 $\mathrm{ng} / \mathrm{ml}, \mathrm{p}<0.001)$. A pre-chemotherapy sHER2 cut-off level of $10 \mathrm{ng} / \mathrm{ml}$ had the best sensitivity and specificity in discriminating between HER2 positive and HER2 negative primary tumors. In HER2 positive patients, we found a significant positive association between pathological complete remission ( $\mathrm{pCR}$ ) and elevated sHER2 levels (above $15 \mathrm{ng} / \mathrm{ml}, \mathrm{p}=0.045$ ) and a decrease of sHER2 levels during NT $(\mathrm{p}=0.02)$, which was also significant in multivariate analysis $(\mathrm{OR}=3.29,95 \%$ CI $1.001-10.89, \mathrm{p}=0.049)$. In HER2 negative patients, we observed no association between sHER2 levels and pCR ( $\mathrm{p}>0.05)$.

Conclusion: Monitoring sHER2 levels in the presence of anti-HER2 treatment might be an adjunct to the clinical evaluation during NT. 


\section{Introduction}

Neoadjuvant treatment (NT) strategies allow the assessment of therapeutic efficacy of chemotherapy and novel targeted approaches in breast cancer patients without long follow-up periods which are required in the adjuvant setting. The German Breast Group and the AGO study group have conducted successful clinical trials in the neoadjuvant setting over the last years [13]. The study GeparQuattro was a phase III trial program that incorporated different NT approaches for primary breast cancer (epirubicin/cyclophosphamide prior to randomization to either docetaxel alone, docetaxel in combination with capecitabine or docetaxel followed by capecitabine) and additional trastuzumab treatment for HER2 positive patients [4,5]. This setting offered an opportunity for translational research projects examining biomarkers that should allow improving the knowledge of mechanisms underlying modern treatment strategies.

Human epidermal growth factor receptor 2 (HER2) is overexpressed in 15-20\% of primary breast cancers. Breast tumors that exhibit HER2 protein overexpression or gene amplification are more aggressive and more likely to recur [6-8]. The HER2 protein is a $185-\mathrm{kDA}$ transmembrane tyrosine kinase receptor with 3 defined domains: the intracellular tyrosine kinase portion, a short transmembrane portion, and the extracellular domain (ECD). This 105-kDa ECD (sHER2) can be cleaved from the surface by metalloproteases and detected in the peripheral blood [9]. It was reported that trastuzumab inhibits HER2 extracellular domain cleavage and that the remaining cleaved HER2 receptor is constitutively activated [10,11], suggesting that the presence of sHER2 also reflects a biologic process leading to a more aggressive tumor behavior [12]. Elevated levels of sHER2 are observed in patients with primary breast cancer [13] or metastatic breast cancer $[14,15]$.

Trastuzumab, a monoclonal antibody directed against HER2, has become a standard treatment in HER2 positive breast cancer patients and has also increased remission rates after neoadjuvant therapy [16]. A number of new treatment approaches directed against HER2 are currently examined in clinical trials, but the optimal use of these compounds is still unclear.

Also, the increasing use of neoadjuvant chemotherapy in patients with primary breast cancer requires the identification of predictive markers of pathologic response which is a surrogate marker of survival $[17,18]$.

The role of sHER2 in the neoadjuvant setting with the use of HER2-targeted therapies is unclear. Therefore, the purpose of this study was to determine sHER2 levels in patients with nonmetastatic breast cancer before NT and after NT prior to surgery. We evaluated the potential utility of sHER2 levels for predicting response to treatment, in particular in patients treated with 
trastuzumab-based regimens, and compared results of a HER2 positive cohort with a HER2 negative patient cohort. 


\section{Material and Methods}

\section{The clinical study Geparquattro}

Patients with either large operable or locally advanced tumors; tumors with negative hormone receptor status; or receptor positive tumors but clinically node-positive disease were recruited to receive preoperatively 4 cycles of epirubicin/cyclophosphamide (EC) $\left(90 \mathrm{mg} / \mathrm{m}^{2} /\right.$ $\left.600 \mathrm{mg} / \mathrm{m}^{2}\right)$ and to be then randomized to either 4 cycles of docetaxel (T) $\left(100 \mathrm{mg} / \mathrm{m}^{2}\right)$ or 4 cycles of $\mathrm{T}+$ capecitabine $(\mathrm{X})\left(75 \mathrm{mg} / \mathrm{m}^{2} / 1800 \mathrm{mg} / \mathrm{m}^{2}\right)(\mathrm{TX})$ or 4 cycles of $\mathrm{T}\left(75 \mathrm{mg} / \mathrm{m}^{2}\right)$ followed by 4 cycles of $\mathrm{X}\left(1800 \mathrm{mg} / \mathrm{m}^{2}\right)(\mathrm{T} \rightarrow \mathrm{X})$. Patients with HER2 positive tumors received trastuzumab (6 mg/kg i.v. every 3 weeks) concomitantly to cytotoxic treatment, starting with a loading dose of $8 \mathrm{mg} / \mathrm{kg}$ i.v. on day 1 of the first EC-cycle. Primary objectives were to assess the effect of $\mathrm{X}$ and to assess the effect of therapy duration. Primary endpoint of the study was pathological complete remission ( $\mathrm{pCR}$ ). Secondary endpoint was breast-conserving therapy. Trastuzumab was given to patients with HER2 positive tumors. HER2 positivity was defined as IHC $3+$ or fluorescence in-situ hybridization (FISH) positive of the primary tumor. The standardized immunohistochemistry assay HercepTest ${ }^{\circledR}$ by DakoCytomation was mandatory and all IHC $2+$ cases had to be centrally analyzed by FISH assay in one of five German reference centers. The trial registration number (at Clinicaltrials.gov) is NCT00288002.

\section{Inclusion criteria for the translational subprotocol and ethical considerations}

Full blood samples before and after chemotherapy were collected for patients eligible for the Geparquattro study in the participating centers. Samples were stored at $-20^{\circ}$ Celsius and shipped on dry ice. All patients gave informed consent to provide a prespecified amount of extra blood before entering the Geparquattro study with the informed consent form. Participation on the clinical trial was still possible if a patient did not agree to provide extra blood samples. Patients were not informed about the laboratory results due to their experimental character. The clinical treatment study as well as the translational research project described here were approved by the central ethics committee at the University of Frankfurt as well as in all ethics committees of the participating centers. The disposition of patients (CONSORT diagram) is shown in the supplementary Fig. 1.

\section{Interventions}

Serum samples were collected in the study centers and send to the German Breast Group. Correct labeling was checked and 175 serum samples (90 of HER2 positive and 85 of HER2 negative patients) were forwarded to the Department of Gynecology, University Medical Center 
Hamburg-Eppendorf. Medical records were stored in a central database at the GBG and the patient identifiers were kept confidential so the assay was performed blinded for the clinical results. After serum determination results were assigned to the medical records and doublechecked. Detailed patient characteristics are listed in Table 1. Patients were randomly selected for inclusion in the study. Since the availability of serum is not based upon tumor size (as it is for tissue), no relevant differences between the patient characteristics of the entire study and this sub-protocol were observed (data not shown).

\section{ELISA}

sHER2 was quantified by a commercially available enzyme-linked immunosorbant assay (Siemens Healthcare Diagnostics Inc., Tarrytown, NY, USA) as previously described [14]. The results were expressed in nanogramme per millilitre (ng/ml). Each sample, standard and control was assayed in duplicate. Inter-assay and intra-assay coefficients of variation were less than $10 \%$. A currently used cut off in the metastatic setting and also recommended by the manufacturer of the assay is $15 \mathrm{ng} / \mathrm{ml}[19,20]$. Therefore, serum levels above $15 \mathrm{ng} / \mathrm{ml}$ were regarded as elevated. Receiver operating curve (ROC) analysis was performed to determine an optimal sHER2 decline during NT corresponding to pCR. A decrease of sHER2 levels of more than 20 per cent during NT was regarded as significant in the following analysis (sensitivity $75 \%$, specificity $55 \%$ ) [21].

\section{Statistical Analysis}

The statistical analysis was performed using SPSS 17.0 software (SPSS, Chicago, IL, USA). Each analysis was performed separately for the HER2 positive and HER2 negative patient cohort. sHER2 levels were plotted against clinicopathological parameters by analysis of variance (ANOVA). The following groups were compared: Tumor size less than $5 \mathrm{~cm}(\mathrm{pT} 1+2)$ versus more than $5 \mathrm{~cm}$ (pT3+4), G1/G2 versus G3; node-positive versus node-negative tumors; estrogen receptor positive versus negative, progesterone receptor positive versus negative; premenopausal versus postmenopausal, age $<40$ years versus $\geq 40$ years and HER2 positive versus HER2 negative primary tumors. Pathological complete remission (pCR) was defined as no microscopic evidence of invasive tumor cells in all resected specimens of the breast and lymph nodes. The correlation between pCR and baseline variables was tested by logistic regression in the univariate and in the multivariate analysis. A two tailed p-value less than 0.05 was considered as statistically significant. The study was performed in accordance to the REMARK criteria published and discussed [22,23]. End point for our analysis was the clinical end point of the study, the pCR, in correlation to absolute values and changes of sHER2 levels. 


\section{Results}

175 patients were included in this analysis (Table 1).

There was no difference between HER2 positive and the 85 HER2 negative patients regarding median age, menopausal status, tumor size, nodal status, grading and rate of breast conserving therapy. In the HER2 negative cohort, more patients were estrogen receptor positive $(p=0.02)$, progesterone receptor positive $(\mathrm{p}=0.01)$ and less patients had a $\mathrm{pCR}(\mathrm{p}<0.001)$. The comparison between HER2 positive and negative patients regarding clinicopathological parameters is listed in Table 2.

\section{Correlation between sHER2 levels and HER2 status}

Pre-chemotherapy sHER2 levels were determined in 167 patients. 89 patients had HER2 positive and 78 patients HER2 negative primary tumors. Median pre-chemotherapy sHER2 levels were higher in patients with positive HER2 status than in patients with negative HER2 status (14.9 $\mathrm{ng} / \mathrm{ml}$ versus $7.7 \mathrm{ng} / \mathrm{ml}, \mathrm{p}<0.001$, figure 1). Post-chemotherapy sHER2 levels ( $\mathrm{n}=164)$ were also associated with HER2 status (median $14.5 \mathrm{ng} / \mathrm{ml}$ in HER2 positive patients versus $8.2 \mathrm{ng} / \mathrm{ml}$ in HER2 negative patients, $\mathrm{p}<0.001)$.

In HER2 positive patients, 44 patients (49\%) had elevated pre-chemotherapy sHER2 levels (above $15 \mathrm{ng} / \mathrm{ml}$ ), 41 patients (46\%) had elevated post-chemotherapy sHER2 levels. In the HER2 negative cohort, only one patient (1\%) had elevated pre- and post-chemotherapy sHER2 levels.

Pre-chemotherapy sHER2 levels above $15 \mathrm{ng} / \mathrm{ml}$ were associated with a positive HER2 status of the primary tumor in 44 of 89 patients (49\%). sHER2 levels below $15 \mathrm{ng} / \mathrm{ml}$ were associated with a negative HER2 status in 77 of 78 patients (99\%). Thus, the specificity of the common sHER2 cut-off value of $15 \mathrm{ng} / \mathrm{ml}$ is high, with a low sensitivity in non-metastatic patients. ROC-curve analysis revealed that a sHER2 cut-off level of $10 \mathrm{ng} / \mathrm{ml}$ had a higher sensitivity of $72 \%$, a specificity of $85 \%$, a positive predictive value of $85 \%$ and a negative predictive value of $73 \%$ in discriminating between positive and negative HER2 status of primary tumors (figure 2).

\section{Change of sHER2 levels during chemotherapy}

In HER2 positive patients, we determined a significant decline of sHER2 levels (> 20\%) during therapy in $49 \%$ of patients $(n=43)$. In HER2 negative patients, we found a significant decline only in $14 \%$ of the patients $(n=12)$. This difference between both groups was statistically significant $(\mathrm{p}=0.039)$.

Regarding only those patients that started with elevated sHER2 levels above $15 \mathrm{ng} / \mathrm{ml}(\mathrm{n}=44)$, a significant decline of sHER2 levels $(>20 \%)$ was seen in $32 \%$ of patients $(n=14)$. No difference in 
sHER2 level changes was seen between the group of patients with hormone receptor positive and hormone receptor negative tumors.

\section{Correlation between sHER2 levels and clinicopathological parameters}

In the HER2 positive cohort, we observed a positive correlation between nodal status and prechemotherapy sHER2 levels $(\mathrm{p}=0.042)$. We observed no other correlations between clinicopathological parameters including age, menopausal status, tumor size, grading, histological type, estrogen and progesterone receptor status and pre-chemotherapy sHER2 levels or post-chemotherapy sHER2 levels.

In the HER2 negative cohort, we observed a positive correlation between pre-chemotherapy sHER2 levels and menopausal status $(\mathrm{p}=0.019)$ and a positive correlation between postchemotherapy sHER2 levels and age $(\mathrm{p}=0.017)$ and estrogen receptor status $(\mathrm{p}=0.012)$.

We found no other statistically significant correlations between pre or post-chemotherapy sHER2 levels and the above mentioned parameters.

\section{pCR in relation to sHER2 levels and clinicopathological parameters}

In HER2 positive patients, we observed an association between pCR and negative hormone receptor status $(\mathrm{p}<0.001$ for $E R$ and $\mathrm{p}=0.002$ for $\mathrm{PR})$, prechemotherapy sHER2 levels above 15 $\mathrm{ng} / \mathrm{ml}(\mathrm{p}=0.045)$ and a decline of sHER2 levels $(>20 \%)$ during NT $(\mathrm{p}=0.02)$ in univariate analysis (table 3). Estrogen receptor status and decline of sHER2 levels (>20\%) correlated with pCR in multivariate analysis adjusted for age, tumor size, nodal status, grading, progesterone receptor status and prechemotherapy sHER2 levels (ER: OR 7.46, 95\% CI 2.73-20.39, p<0.001 and decline of sHER2 levels: OR=3.29, 95\% CI $1.001-10.89, \mathrm{p}=0.049$, data not shown.

In the HER2 positive patient cohort, patients with pCR had higher sHER2 levels before chemotherapy than patients with no pCR (median $17.7 \mathrm{ng} / \mathrm{ml}$ versus $13.1 \mathrm{ng} / \mathrm{ml}, \mathrm{p}=0.013$ ). After the end of chemotherapy, sHER2 levels did not differ between patients with pCR or no pCR (median $15.2 \mathrm{ng} / \mathrm{ml}$ versus $13.6 \mathrm{ng} / \mathrm{ml}, \mathrm{p}=\mathrm{n} . \mathrm{s}$.). HER2 positive patients with $\mathrm{pCR}$ had a median decrease of sHER2 levels of $26 \%$ in comparison to a median decrease of $10 \%$ in HER2 positive patients without $\mathrm{pCR}(\mathrm{p}=0.023)$.

In conclusion, HER2 positive patients with sHER2 levels above $15 \mathrm{ng} / \mathrm{ml}$ before therapy or patients with a minimum decline of sHER2 levels of $20 \%$ during therapy had a $60 \%$ higher probability of achieving a pCR than patients with sHER2 levels below $15 \mathrm{ng} / \mathrm{ml}$ or patients with a decline of less than $20 \%$ during therapy. 
In HER2 negative patients, only negative progesterone receptor status correlated with pCR in univariate $(\mathrm{p}=0.001)$ as well as in multivariate analysis adjusted for the above mentioned parameters (OR 16.2, 95\% CI $1.41-186.85, \mathrm{p}=0.026$ ), but no such differences were observed for patients with or without pCR with regard to sHER2 levels before and after chemotherapy. Detailed information about pCR and elevated sHER2 levels as well as change of sHER2 levels during NT in the HER2 positive and negative patient cohort is listed in table 4.

\section{Breast-conserving therapy in relation to sHER2 levels and clinicopathological parameters}

In HER2 positive patients, breast-conserving therapy was associated with smaller tumor size $(\mathrm{p}<0.001)$ and decline of sHER2 levels $(\mathrm{p}=0.035)$ in univariate analysis and only with smaller tumor size in multivariate analysis ( $\mathrm{OR}=0.17,95 \%$-CI $0.06-0.48, \mathrm{p}=0.001$, data not shown).

In HER2 negative patients, only smaller tumor size correlated with breast-conserving therapy in univarariate $(\mathrm{p}<0.001)$ and multivariate analysis $(\mathrm{OR}=0.4,95 \%$-CI $0.18-0.71, \mathrm{p}=0.003$, data not shown), but no such correlation was observed for sHER2 levels or decline of serum levels. 


\section{Discussion}

Pathologic complete response to induction chemotherapy is considered an important surrogate marker for long term outcome of patients with primary breast cancer undergoing neoadjuvant chemotherapy. Since no long follow up periods are required, this setting is used for the development of new treatment strategies and biomarker evaluation. To our knowledge, the present study is the largest one to evaluate sHER2 levels in the context of trastuzumab treatment in the neoadjuvant setting. Furthermore, a HER2 negative cohort was selected as comparison group.

HER2 is a prominent therapeutic target in breast cancer and trastuzumab, a monoclonal antibody against this epidermal growth factor receptor, prolongs survival in the adjuvant and metastatic setting [24,25]. The expression of HER2 in primary tumors is essential for trastuzumab treatment decisions of breast cancer patients [24]. However, the optimal use of trastuzumab and the various other drugs targeting HER2 that are currently in different phases of development are not clear yet. In the neoadjuvant setting, the effect of different therapies can be evaluated as the tumor is removed after treatment and tissue can be examined. In this context, different targeted therapy approaches are currently evaluated in clinical trials. The role of sHER2 in the adjuvant or neoadjuvant setting is still not well defined [26].

The sHER2 ELISA system used in our study was approved by the US Food and Drug Administration in the year 2000. The currently approved cut-off for an elevated sHER2 is greater than $15 \mathrm{ng} / \mathrm{ml}$ and, circulating trastuzumab has been shown not to interfere with the assay [27] because the antibodies used recognize different and non-overlapping epitopes on the extracellular domain (ECD) than trastuzumab. Most published studies found no correlation between serum and tissue HER2 status among women with newly diagnosed breast cancer. Before initiation of neoadjuvant chemotherapy, Köstler et al. found the HER2 ELISA to have a sensitivity of $28 \%$ in 39 HER2 positive patients (FISH) [28] and Mazouni et al. reported a sensitivity of 56\% in 16 HER2 positive patients (IHC) with a cut-off of $15 \mathrm{ng} / \mathrm{ml}$ [29]. This is in line with our finding that the cut-off of $15 \mathrm{ng} / \mathrm{ml}$ has a low sensitivity, but high specificity in predicting the HER2 status of the primary tumor. This fact suggests that some women with HER2-negative tumors secrete detectable amounts of sHER2. However, we found no association between tumor size and sHER2 levels which was described as a parameter that might increase sHER2 levels [30,31]. We found a positive association between nodal status and sHER2 in HER2 positive patients and between age and sHER2 in HER2 negative patients. In our patient cohort, ROC-curve analysis showed that a cut-off level of $10 \mathrm{ng} / \mathrm{ml}$ had a sensitivity of $72 \%$ and a specificity of $85 \%$ in 
predicting the HER2 status of the primary tumor. In contrast, Quaranta et al. could not find a correlation between serum and tissue HER2 levels in an unselected patient group of 108 patients using the same cut-off as we did (10ng/ml) [32].

In metastatic breast cancer, no clear relationship was found between baseline sHER2 levels and tumor response to trastuzumab based treatment in a recently published metaanalysis [33], while other groups have suggested a role of sHER2 determination $[21,34]$ so that no definitive conclusions can be drawn [26]. There is limited information regarding sHER2 to predict benefit from trastuzumab treatment in primary breast cancer. None of the recent adjuvant trastuzumab trials have published an analysis of sHER2 [35]. The rationale of determining sHER2 with no primary tumor present seems weak. In our randomized NT-trial, we could show in a relatively large number of patients that elevated sHER2 levels above $15 \mathrm{ng} / \mathrm{ml}$ as well as a decrease of sHER2 levels of more than $20 \%$ from the beginning of NT to the end of NT was associated with pCR in HER2 positive patients. This effect was observed in univariate and multivariate analysis. Two smaller published reports investigated the correlation between pretreatment sHER2 and pathologic complete response during neoadjuvant chemotherapy plus trastuzumab. Köstler et al. evaluated sHER2 levels in a trastuzumab-based neoadjuvant setting in 16 patients. In this small group of patients, they could show that a decrease of sHER2 levels was associated with response to therapy [28]. In 39 patients with NT-treatment, 29 patients receiving a trastuzumab combination, Mazouni et al. could only find a role of decreasing sHER2 levels in predicting therapy response from week 3 to week 6 after therapy initiation [29].

In our patient group, sHER2 levels were higher in HER2 positive patients than in HER2 negative patients before initiation of chemotherapy and also after finalization of chemotherapy. The fact that sHER2 levels were not associated with tumor size supports the hypothesis that secretion of HER2 is dependent on biologic mechanisms like active shedding. One potential drawback of our study is the fact that we have no sHER2 determination after surgery since the ethics approval did not allow blood sampling at this time point. Therefore, we are not able to determine if sHER2 after chemotherapy was secreted only by the primary tumor. Also, previously published studies in patients with metastatic breast cancer have reported potential benefits of more dense serum HER2 monitoring and therefore, earlier determination of serum HER2 would have been of interest [33]. Differences between the HER2 positive and negative patient cohort concerning $\mathrm{pCR}$ and estrogen receptor status in our patient group are representative of the whole study population. Also in other patient cohorts, a positive HER2 status of the primary tumor was associated with negative hormone receptor status and pCR rates 
were higher in patients receiving trastuzumab treatment $[16,36]$. Therefore, it seems unlikely that the differences between the two cohorts are based on a selection bias.

Forty-nine per cent of HER2 positive patients and only 14\% of HER2 negative patients had a decline of sHER2 levels of more than $20 \%$ during chemotherapy. It was described that shedding of the HER2 extracellular domain was inhibited by trastuzumab [10]. In the HER2 positive patient cohort, median prechemotherapy sHER2 levels were significantly higher in patients with pCR than in patients without $\mathrm{pCR}$ and the median decrease of sHER2 levels during therapy was also higher in patients with pCR. However, we were not able to find a specific cutoff level that was able to discriminate between patients with and without pCR. This is in concordance with findings in the metastatic setting, where the baseline level of sHER 2 alone was not a predictor of response to treatment $[14,37]$. Moreover, we were not able to add further information to our analysis regarding different subsets of patients. In contrast to our findings, in the series reported by Mazouni et al in the neoadjuvant setting, mean sHER2 baseline values were not different between the pCR group and the group with residual disease [29]. In the current report, we can summarize that patients who did not have a significant decline $(>20 \%)$ in sHERs levels had decreased benefit from trastuzumab-based therapy. Possible mechanisms of trastuzumab resistance include altered receptor antibody interaction, PTEN loss and enhanced Akt signaling, p27 loss, signaling through other receptors [38].

Monitoring changes in sHER2 levels after a specific time-period after trastuzumab treatment to predict clinical response might be valuable for identifying a patient population that might benefit from additional treatment regimens with other HER2 targeted therapies. Prospective clinical trials evaluating the use of other HER-2-directed therapies (e.g., receptor antibodies, sheddase inhibitors, signal transduction inhibitors, heat shock protein inhibitors, proteasome inhibitors, anti-angiogenic agents and immune-stimulatory therapies) with and without continued trastuzumab therapy are currently in development to exploit the pathway following the onset of resistance. Since the truncated receptor might not be ideally treated with trastuzumab but rather with agents targeting the intracellular region of the receptor like the tyrosine kinase inhibitor lapatinib [39], the determination of sHER2 levels might be useful in this context. Serum samples can be easily obtained and repeated determinations can be performed. Based on these considerations, we will investigate sHER2 levels in the currently ongoing neoadjuvant GeparQuinto trial where HER2 positive patients receive either trastuzumab or lapatinib in addition to chemotherapy. Therefore, our findings form the basis for further studies which may lead to an improvement of current treatment strategies. 


\section{Acknowledgements:}

Authors` disclosures of potential conflict of interest: Advisory Role/Relationship: Sibylle

Loibl, Roche; Jens Huober, Roche; Claus Hanusch, Sanofi Aventis; Hans Tesch, Roche;

Volkmar Müller, Roche. Honoraria: Sibylle Loibl, Roche; Gunter von Minckwitz, Roche; Claus

Hanusch, Sanofi Aventis; Hans Tesch, Roche; Volkmar Müller, Roche. Research funding:

Christoph Mundhenke, Novartis Oncology; Volkmar Müller, Roche and Siemens Diagnostics. All other authors have declared no conflict of interest.

We thank Sylke Krenkel for excellent technical assistance and the staff of the German Breast Group for support of this translational research project. Most of all, we thank the patients of the clinical trial GeparQuattro who participated in this substudy. 
Table 1: Baseline characteristics of patients with HER2 positive tumors and the reference group with HER2 negative tumors before and after neoadjuvant therapy (NT)

\begin{tabular}{|c|c|c|c|c|c|c|c|c|}
\hline \multirow[b]{3}{*}{ Parameter } & \multicolumn{4}{|c|}{ HER2 positive } & \multicolumn{4}{|c|}{ HER2 negative } \\
\hline & \multicolumn{2}{|c|}{ Before NT } & \multicolumn{2}{|c|}{ After NT } & \multicolumn{2}{|c|}{ Before NT } & \multicolumn{2}{|c|}{ After NT } \\
\hline & No. & $\%$ & No. & $\%$ & No. & $\%$ & No. & $\%$ \\
\hline \multicolumn{9}{|l|}{ Tumor size } \\
\hline Tis/T0 & & & 45 & 52.3 & & & 12 & 15.4 \\
\hline T1 & 4 & 4.7 & 28 & 32.6 & 2 & 2.4 & 37 & 47.4 \\
\hline $\mathbf{T 2}$ & 66 & 77.7 & 12 & 14.0 & 60 & 70.6 & 24 & 30.8 \\
\hline T3 & 11 & 12.9 & 1 & 1.1 & 11 & 12.9 & 4 & 5.1 \\
\hline $\mathbf{T 4}$ & 4 & 4.7 & 0 & 0 & 12 & 14.1 & 1 & 1.3 \\
\hline missing & 5 & & 4 & & & & 7 & \\
\hline \multicolumn{9}{|l|}{ Nuclear grading } \\
\hline$(\mathbf{p C R})$ & & & 32 & 44.4 & & & 7 & 9.1 \\
\hline G1 & 2 & 2.3 & 2 & 2.8 & 6 & 7.3 & 3 & 3.9 \\
\hline G2 & 52 & 60.5 & 30 & 41.7 & 50 & 61.0 & 43 & 55.8 \\
\hline G3 & 32 & 37.2 & 8 & 11.1 & 26 & 31.7 & 24 & 31.2 \\
\hline missing & 4 & & 18 & & 3 & & 8 & \\
\hline \multicolumn{9}{|c|}{ Estrogen receptor status } \\
\hline (pCR) & & & 25 & 34.3 & & & 7 & 10.8 \\
\hline ER pos/PR pos & 31 & 34.4 & 20 & 27.4 & 49 & 57.7 & 32 & 49.2 \\
\hline ER pos/PR neg & 11 & 12.2 & 7 & 9.6 & 6 & 7.1 & 7 & 10.8 \\
\hline ER neg/PR pos & 6 & 6.7 & 1 & 1.4 & 3 & 3.5 & 3 & 4.6 \\
\hline ER neg/PR neg & 42 & 46.7 & 20 & 27.4 & 27 & 31.8 & 16 & 24.6 \\
\hline missing & & & 17 & & & & 20 & \\
\hline \multicolumn{9}{|l|}{ Nodal status } \\
\hline Negative & 39 & 43.3 & 71 & 79.8 & 37 & 43.5 & 33 & 41.8 \\
\hline Positive & 51 & 56.7 & 18 & 20.2 & 48 & 56.5 & 46 & 58.2 \\
\hline missing & & & 1 & & & & 6 & \\
\hline
\end{tabular}


Table 2: Comparison of the distribution of clinicopathological parameters in the HER2 positive and negative patient cohort

\begin{tabular}{lccc}
\hline & HER2 positive & HER2 negative & p-value \\
\hline Age [median] & 48 yrs. & 47 yrs. & n.s. \\
Premenopausal status & $54 / 90(60 \%)$ & $53 / 85(62 \%)$ & n.s. \\
Large Tumor size (T3+T4) & $20 / 90(22 \%)$ & $23 / 85(27 \%)$ & n.s. \\
Nodal status (positive) & $51 / 90(57 \%)$ & $48 / 85(57 \%)$ & n.s. \\
High grading (G3) & $32 / 90(36 \%)$ & $26 / 85(31 \%)$ & n.s. \\
ER positive & $42 / 90(47 \%)$ & $55 / 85(65 \%)$ & $\mathbf{p = 0 . 0 2}$ \\
PR positive & $37 / 90(41 \%)$ & $52 / 85(61 \%)$ & $\mathbf{p = 0 . 0 1}$ \\
pCR & $44 / 90(49 \%)$ & $12 / 85(14 \%)$ & $\mathbf{p}<\mathbf{0 . 0 0 1}$ \\
BCT & $60 / 90(67 \%)$ & $54 / 85(64 \%)$ & n.s.
\end{tabular}

Significant differences between the patient cohorts are printed in bold 
Table 3: Correlation of clinicopathological parameters with pathological complete remission in the HER2 positive patient cohort

\begin{tabular}{lll}
\hline Baseline characteristics & Odds Ratio & p-value \\
\hline T3/4 vs. T1/2 & 0.39 & n.s. \\
G3 vs. G1/2 & 1.5 & n.s. \\
cN1 vs. cN0 & 1.25 & \\
ER neg vs. ER pos* & 4.99 & $\mathbf{p}<\mathbf{0 . 0 0 1}$ \\
PR neg vs. PR pos & 3.17 & $\mathbf{p}=\mathbf{0 . 0 0 2}$ \\
sHER2 $>$ 15 mg/ml vs. sHER2 $<15 \mathrm{ng} / \mathrm{ml}$ & 2.03 & $\mathbf{p = 0 . 0 4 5}$ \\
sHER2 decrease $>20 \%$ vs. sHER2 decrease $<=20 \% *$ & 2.36 & $\mathbf{p = 0 . 0 2}$ \\
\hline
\end{tabular}

* also significant in multivariate analysis, significant values are printed in bold 
Table 4: sHER2 levels in association with pathological complete remission (pCR) in the HER2 positive and HER2 negative patient cohort

$\mathrm{pCR}$ in

\begin{tabular}{|c|c|}
\hline HER2 positive cohort & HER2 negative cohort \\
\hline No. & No. \\
\hline
\end{tabular}

Pre-chemotherapy sHER2 levels

$\begin{array}{lcccc}\text { sHER2 }>15 \mathrm{ng} / \mathrm{ml} & 26 / 43 & 60.5 & 0 / 10 & 0 \\ \mathrm{sHER} 2<=15 \mathrm{ng} / \mathrm{ml} & 18 / 46 & 39.1 & 10 / 10 & 100\end{array}$

Decrease of sHER2 during NT

$\begin{array}{lllll}>20 \% & 25 / 41 & 61.0 & 2 / 10 & 20.0 \\ <=20 \% & 16 / 41 & 39.0 & 8 / 10 & 80.0\end{array}$




\section{References}

1. Kaufmann M, von Minckwitz G, Smith R, Valero V, Gianni L, Eiermann W, Howell A, Costa SD, Beuzeboc P, Untch M, Blohmer JU, Sinn HP, Sittek R, Souchon R, Tulusan AH, Volm T and Senn HJ (2003) International expert panel on the use of primary (preoperative) systemic treatment of operable breast cancer: review and recommendations. J Clin Oncol, 21, 2600-8.

2. von Minckwitz G, Raab G, Caputo A, Schutte M, Hilfrich J, Blohmer JU, Gerber B, Costa SD, Merkle E, Eidtmann H, Lampe D, Jackisch C, du Bois A and Kaufmann M (2005) Doxorubicin with cyclophosphamide followed by docetaxel every 21 days compared with doxorubicin and docetaxel every 14 days as preoperative treatment in operable breast cancer: the GEPARDUO study of the German Breast Group. J Clin Oncol, 23, 2676-85.

3. Untch M, Mobus V, Kuhn W, Muck BR, Thomssen C, Bauerfeind I, Harbeck N, Werner C, Lebeau A, Schneeweiss A, Kahlert S, von Koch F, Petry KU, Wallwiener D, Kreienberg R, Albert US, Luck HJ, Hinke A, Janicke F and Konecny GE (2009) Intensive dose-dense compared with conventionally scheduled preoperative chemotherapy for high-risk primary breast cancer. J Clin Oncol, 27, 2938-45.

4. von Minckwitz G, Rezai M, Loibl S, Fasching PA, Huober J, Tesch H, Bauerfeind I, Hilfrich J, Eidtmann H, Gerber B, Hanusch C, Kuhn T, du Bois A, Blohmer JU, Thomssen C, Dan Costa S, Jackisch C, Kaufmann M, Mehta K and Untch M (2010) Capecitabine in Addition to Anthracycline- and Taxane-Based Neoadjuvant Treatment in Patients With Primary Breast Cancer: Phase III GeparQuattro Study. Journal of Clinical Oncology, published ahead of print on March 22.

5. Untch M, Rezai M, Loibl S, Fasching PA, Huober J, Tesch H, Bauerfeind I, Hilfrich J, Eidtmann H, Gerber B, Hanusch C, Kuhn T, du Bois A, Blohmer JU, Thomssen C, Dan Costa S, Jackisch C, Kaufmann M, Mehta K and von Minckwitz G (2010) Neoadju vant Treatment With Trastuzumab in HER2-Positive Breast Cancer: Results From the GeparQuattro Study. Journal of Clinical Oncology, published ahead of print on March 22.

6. Slamon DJ, Clark GM, Wong SG, Levin WJ, Ullrich A and McGuire WL (1987) Human breast cancer: correlation of relapse and survival with amplification of the HER-2/neu oncogene. Science, 235, 177-182.

7. Slamon DJ, Godolphin W, Jones LA, Holt JA, Wong SG, Keith DE, Levin WJ, Stuart SG, Udove J and Ullrich A (1989) Studies of the HER-2/neu proto-oncogene in human breast and ovarian cancer. Science, 244, 707-712.

8. Paik S, Bryant J, Tan-Chiu E, Yothers G, Park C, Wickerham DL and Wolmark N (2000) HER2 and choice of adjuvant chemotherapy for invasive breast cancer: National Surgical Adjuvant Breast and Bowel Project Protocol B-15. J.Natl.Cancer Inst., 92, 1991-198.

9. Codony-Servat J, Albanell J, Lopez-Talavera JC, Arribas J and Baselga J (1999) Cleavage of the HER2 ectodomain is a pervanadate-activable process that is inhibited by the tissue inhibitor of metalloproteases-1 in breast cancer cells. Cancer Res., 59, 11961201.

10. Molina MA, Codony-Servat J, Albanell J, Rojo F, Arribas J and Baselga J (2001) Trastuzumab (herceptin), a humanized anti-Her2 receptor monoclonal antibody, inhibits basal and activated Her2 ectodomain cleavage in breast cancer cells. Cancer Res., 61, 4744-4749.

11. Hudelist G, Kostler WJ, Attems J, Czerwenka K, Muller R, Manavi M, Steger GG, Kubista E, Zielinski CC and Singer CF (2003) Her-2/neu-triggered intracellular tyrosine 
kinase activation: in vivo relevance of ligand-independent activation mechanisms and impact upon the efficacy of trastuzumab-based treatment. Br J Cancer, 89, 983-91.

12. Molina MA, Saez R, Ramsey EE, Garcia-Barchino MJ, Rojo F, Evans AJ, Albanell J, Keenan EJ, Lluch A, Garcia-Conde J, Baselga J and Clinton GM (2002) NH(2)-terminal truncated HER-2 protein but not full-length receptor is associated with nodal metastasis in human breast cancer. Clin.Cancer Res., 8, 347-353.

13. Schwartz MK, Smith C, Schwartz DC, Dnistrian A and Neiman I (2000) Monitoring therapy by serum HER-2/neu. Int. J. Biol. Markers, 15, 324-329.

14. Mueller V, Witzel I, Luck HJ, Kohler G, von Minckwitz G, Mobus V, Sattler D, Wilczak W, Loning T, Jaenicke F, Pantel K and Thomssen C (2004) Prognostic and predictive impact of the HER-2/ neu extracellular domain (ECD) in the serum of patients treated with chemotherapy for metastatic breast cancer. Breast Cancer Res Treat, 86, 9-18.

15. Esteva FJ, Cheli CD, Fritsche H, Fornier M, Slamon D, Thiel R, Luftner D and Ghani F (2005) Clinical utility of serum HER2/neu in monitoring and prediction of progressionfree survival in metastatic breast cancer patients treated with trastuzumab-based therapies. Breast Can Res, 7, R436-R443.

16. Buzdar AU, Ibrahim NK, Francis D, Booser DJ, Thomas ES, Theriault RL, Pusztai L, Green MC, Arun BK, Giordano SH, Cristofanilli M, Frye DK, Smith TL, Hunt KK, Singletary SE, Sahin AA, Ewer MS, Buchholz TA, Berry D and Hortobagyi GN (2005) Significantly higher pathologic complete remission rate after neoadjuvant therapy with trastuzumab, paclitaxel, and epirubicin chemotherapy: results of a randomized trial in human epidermal growth factor receptor 2-positive operable breast cancer. J Clin Oncol, 23, 3676-85.

17. Symmans WF, Peintinger F, Hatzis C, Rajan R, Kuerer H, Valero V, Assad L, Poniecka A, Hennessy B, Green M, Buzdar AU, Singletary SE, Hortobagyi GN and Pusztai L (2007) Measurement of residual breast cancer burden to predict survival after neoadjuvant chemotherapy. J Clin Oncol, 25, 4414-22.

18. Tewari M, Krishnamurthy A and Shukla HS (2008) Predictive markers of response to neoadjuvant chemotherapy in breast cancer. Surg Oncol, 17, 301-11.

19. Lipton A, Ali SM, Leitzel K, Demers L, Chinchilli V, Engle L, Harvey HA, Brady C, Nalin CM, Dugan M, Carney W and Allard J (2002) Elevated serum her-2/neu level predicts decreased response to hormone therapy in metastatic breast cancer. J. Clin. Oncol., 20, 1467-1472.

20. Esteva FJ, Valero V, Booser D, Guerra LT, Murray JL, Pusztai L, Cristofanilli M, Arun B, Esmaeli B, Fritsche HA, Sneige N, Smith TL and Hortobagyi GN (2002) Phase II study of weekly docetaxel and trastuzumab for patients with HER-2-overexpressing metastatic breast cancer. J Clin Oncol, 20, 1800-8.

21. Ali SM, Carney WP, Esteva FJ, Fornier M, Harris L, Kostler WJ, Lotz JP, Luftner D, Pichon MF and Lipton A (2008) Serum HER-2/neu and relative resistance to trastuzumab-based therapy in patients with metastatic breast cancer. Cancer, 113, 1294301.

22. Hayes DF, Ethier S and Lippman ME (2006) New guidelines for reporting of tumor marker studies in breast cancer research and treatment: REMARK. Breast Cancer Res Treat, 100, 237-8.

23. McShane LM, Altman DG, Sauerbrei W, Taube SE, Gion M and Clark GM (2005) Reporting recommendations for tumor marker prognostic studies (REMARK). J Natl Cancer Inst, 97, 1180-4.

24. Piccart-Gebhart MJ, Procter M, Leyland-Jones B, Goldhirsch A, Untch M, Smith I, Gianni L, Baselga J, Bell R, Jackisch C, Cameron D, Dowsett M, Barrios CH, Steger G, 
Huang CS, Andersson M, Inbar M, Lichinitser M, Lang I, Nitz U, Iwata H, Thomssen C, Lohrisch C, Suter TM, Ruschoff J, Suto T, Greatorex V, Ward C, Straehle C, McFadden E, Dolci MS and Gelber RD (2005) Trastuzumab after adjuvant chemotherapy in HER2positive breast cancer. N Engl J Med, 353, 1659-72.

25. Hall PS and Cameron DA (2009) Current perspective - trastuzumab. Eur J Cancer, 45, 12-8.

26. Ali SM, Leitzel K, Lipton A, Carney WP and Kostler WJ (2009) Value of Serum Human Epidermal Growth Factor Receptor 2 (HER2)/neu Testing for Early Prediction of Response to HER2/neu-Directed Therapies Is Still an Open One and Deserves Further Study in Large Prospective Trials. J Clin Oncol.

27. Payne RC, Allard JW, Anderson-Mauser L, Humphreys JD, Tenney DY and Morris DL (2000) Automated assay for HER-2/neu in serum. Clin Chem, 46, 175-82.

28. Köstler WJ, Steger GG, Soleiman A, Schwab B, Singer CF, Tomek S, Brodowicz T, Krainer M, Wiltschke C, Horvat R, Jakesz R and Zielinski CC (2004) Monitoring of serum Her-2/neu predicts histopathological response to neoadjuvant trastuzumab-based therapy for breast cancer. Anticancer Res, 24, 1127-30.

29. Mazouni C, Hall A, Broglio K, Fritsche H, Andre F, Esteva FJ, Hortobagyi GN, Buzdar AU, Pusztai L and Cristofanilli M (2007) Kinetics of serum HER-2/neu changes in patients with HER-2-positive primary breast cancer after initiation of primary chemotherapy. Cancer, 109, 496-501.

30. Pallud C, Guinebretiere JM, Guepratte S, Hacene K, Neumann R, Carney W and Pichon MF (2005) Tissue expression and serum levels of the oncoprotein HER-2/neu in 157 primary breast tumours. Anticancer Res, 25, 1433-40.

31. Molina R, Filella X, Zanon G, Pahisa J, Alicarte J, Munoz M, Farrus B and Ballesta AM (2003) Prospective evaluation of tumor markers (c-erbB-2 oncoprotein, CEA and CA 15.3) in patients with locoregional breast cancer. Anticancer Res, 23, 1043-50.

32. Quaranta M, Daniele A, Coviello M, Savonarola A, Abbate I, Venneri MT, Paradiso A, Stea B, Zito A, Labriola A and Schittulli F (2006) c-erbB-2 protein level in tissue and sera of breast cancer patients: a possibly useful clinical correlation. Tumori, 92, 311-7.

33. Lennon S, Barton C, Banken L, Gianni L, Marty M, Baselga J and Leyland-Jones B (2009) Utility of serum HER2 extracellular domain assessment in clinical decision making: pooled analysis of four trials of trastuzumab in metastatic breast cancer. J Clin Oncol, 27, 1685-93.

34. Fornier MN, Seidman AD, Schwartz MK, Ghani F, Thiel R, Norton L and Hudis C (2005) Serum HER2 extracellular domain in metastatic breast cancer patients treated with weekly trastuzumab and paclitaxel: association with HER2 status by immunohistochemistry and fluorescence in situ hybridization and with response rate. Ann Oncol, 16, 234-9.

35. Leary AF, Hanna WM, van de Vijver MJ, Penault-Llorca F, Ruschoff J, Osamura RY, Bilous M and Dowsett M (2009) Value and limitations of measuring HER-2 extracellular domain in the serum of breast cancer patients. J Clin Oncol, 27, 1694-705.

36. Konecny G, Pauletti G, Pegram M, Untch M, Dandekar S, Aguilar Z, Wilson C, Rong HM, Bauerfeind I, Felber M, Wang HJ, Beryt M, Seshadri R, Hepp H and Slamon DJ (2003) Quantitative association between HER-2/neu and steroid hormone receptors in hormone receptor-positive primary breast cancer. J Natl Cancer Inst, 95, 142-53.

37. Köstler WJ, Schwab B, Singer CF, Neumann R, Rucklinger E, Brodowicz T, Tomek S, Niedermayr M, Hejna M, Steger GG, Krainer M, Wiltschke C and Zielinski CC (2004) Monitoring of serum Her-2/neu predicts response and progression-free survival to 
trastuzumab-based treatment in patients with metastatic breast cancer. Clin Cancer Res, $10,1618-24$.

38. Bedard PL, de Azambuja E and Cardoso F (2009) Beyond trastuzumab: overcoming resistance to targeted HER-2 therapy in breast cancer. Curr Cancer Drug Targets, 9, 14862.

39. Scaltriti M, Rojo F, Ocana A, Anido J, Guzman M, Cortes J, Di Cosimo S, Matias-Guiu X, Ramon y Cajal S, Arribas J and Baselga J (2007) Expression of p95HER2, a truncated form of the HER2 receptor, and response to anti-HER2 therapies in breast cancer. J Natl Cancer Inst, 99, 628-38. 


\section{Figure Legends}

Figure 1: sHER2 levels before initiation of chemotherapy in HER2 positive and HER2 negative patients. SHER2 levels are significantly higher in HER2 positive patients than in HER2 negative patients $(\mathrm{p}<0.001)$.

Figure 2: Receiver Operating Characteristic (ROC) curve for different sHER2 cut-off points corresponding to the HER2 status of the primary tumor. A sHER2 cut-off of 10ng/ml has a sensitivity of $72 \%$ and a specificity of $85 \%$ in discriminating between HER2 positive and HER2 negative tumors.

Supplementary Figure 1: Disposition of patients (CONSORT diagram). 